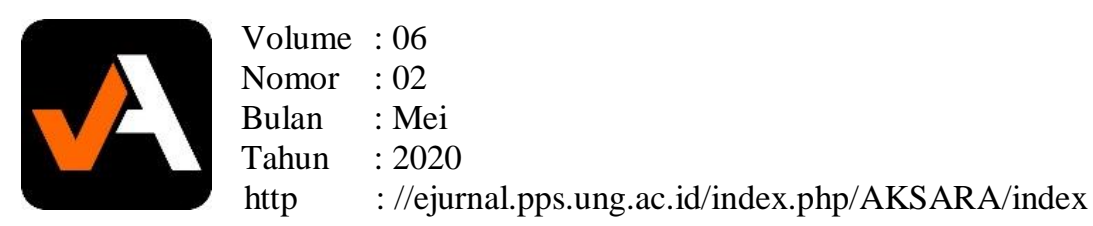

\title{
Analisis Keterampilan Menulis Teks Drama dengan Pembelajaran Quantum
}

\author{
Heni Novitasari, Sutrimah, Cahyo Hasanudin \\ Fakultas Pendidikan Bahasa dan Seni, IKIP PGRI BOJONEGORO \\ E.mail: heninovitasari788@gmail.com
}

Received: 23 Februari 2020; Revised: 27 April 2020; Accepted: 28 April 2020

DOI: http://dx.doi.org/10.37905/aksara.6.2.191-202.2020

\begin{abstract}
Abstrak
Penelitian ini bertujuan untuk mengetahui bentuk teks drama yang ditulis oleh siswa kelas VIII MTs. Darussalam Deru, Sumberrejo, Bojonegoro, Indonesia pada pembelajaran quantum. Penelitian ini adalah penelitian kualitatif dengan menggunakan pendekatan studi kasus dengan jumlah subjek 28 siswa. Dari 28 siswa kemudian peneliti mengambil 5 siswa untuk diwawancarai dengan alasan teks dramanya sesuai dengan indikator. Teknik pengumpulan data menggunakan obsevasi, metode tes, wawancara, dan dokumentasi. Data divalidasi dengan menggunakan triangulasi sumber data dan triangulasi metode. Teknik analisis data menggunakan metode content analysis yang dimulai dari 1) reduksi data, 2) penyajian data, 3) penarikan simpulan dan verifikasi. Hasil penelitian menunjukkan bahwa struktur teks drama yang ditulis oleh siswa kelas VIII MTs. Darussalam Deru, Sumberrejo, Bojonegoro, Indonesia sudah mengacu pada struktur teks drama sesuai dengan teori Kosasih dengan baik. Simpulan pada penelitian ini adalah pembelajaran quantum sangat tepat diterapkan pada pembelajaran. Pembelajaran quantum melatih otak kanan dan kiri untuk berpikir kreatif dan mempunyai pengetahuan yang luas.
\end{abstract}

Kata Kunci

Teks drama, pembelajaran quantum

\section{Pendahuluan}

Empat keterampilan berbahasa pada pelajaran bahasa Indonesia yaitu keterampilan menyimak, keterampilan berbicara, keterampilan membaca, dan keterampilan menulis. Keempat keterampilan tersebut berkaitan satu sama lain. Salah satu keterampilan yang harus dimiliki oleh siswa adalah keterampilan menulis. Kegiatan menulis merupakan suatu hal yang kompleks. Menurut Hidayah, Darmuki, \& Hasanudin (2019) menulis merupakan suatu aktivitas penting pada proses pembelajaran karena dengan menulis sesorang dapat memperoleh ilmu yang tidak akan terkikis oleh zaman. Menurut Sobari (2012) menulis adalah aktivitas untuk melahirkan pikiran serta perasaan yang tersaji secara sistematis dan memikat. Kegiatan menulis bukan hanya sekedar mengemukakan gagasan atau perasaan penulis, akan tetapi juga mengungkapkan ilmu, pengetahuan serta pengalaman penulis ke dalam sebuah tulisan (Pratiwi, 2018).

Salah satu bentuk pembelajaran menulis adalah menulis teks drama. Menulis teks drama ditemukan pada kurikulum 2013 kompetensi dasar (KD) 4.16 yakni menyajikan drama ke dalam bentuk pentas atau naskah. Berdasarkan hal tersebut, tujuan akhir dari kompetensi dasar ini adalah siswa mampu menyajikan drama dalam bentuk pentas atau naskah. Drama merupakan sebuah seni pementasan yang memainkan peran, baik di panggung maupun tidak (Rahimah, Priyadi, \& Syambasril, 2018). Sebagai salah satu 


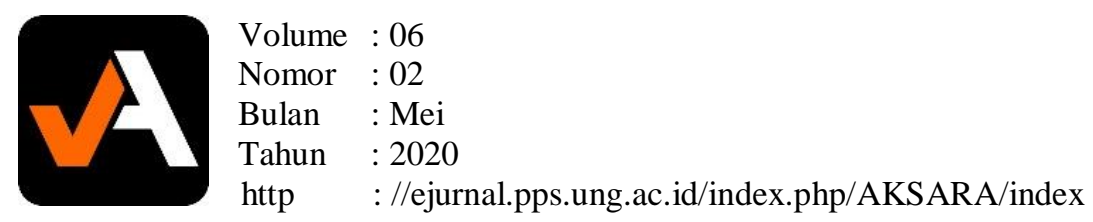

karya sastra, drama tidak lepas dari penggunaan bahasa. Bahasa pada drama berbentuk dialog berisi percakapan antar tokoh untuk kemudian diperankan dan dipertunjukkan. Menurut Yusandra (2017) konten pada drama yang diutamakan adalah dialog atau ucapan pemeran. Dialog antara pemeran satu dengan yang lainnya menunjukkan kejadian dan suatu persoalan yang hendak diungkapkan oleh penulis. Jadi dapat disimpulkan bahwa drama adalah sebuah karya sastra yang berbentuk dialog yang berisi suatu kejadian serta persoalan antar tokoh kemudian dipentaskan.

Menurut Tambunan dan Naelofaria (2019) teks drama adalah salah satu karya sastra berbentuk fiksi yang berisi kisah kehidupan dalam wujud dialog. Teks drama adalah sebuah teks yang mengandung cerita yang diperankan oleh setiap tokoh (Iswara, 2019). Menurut Permanasari (2019) Teks drama adalah karya tulis yang memuat kisah (lakon). Teks drama dapat menggambarkan watak, nasib serta konflik antar tokoh yang diperankan. Menulis teks drama melibatkan daya imajinasi penulis sehingga dapat memiliki cerita yang runtut. Menulis teks drama merupakan salah satu bentuk apresiasi sastra tingkat produktif. Menurut Sayuti dalam Satinem (2019) apresiasi sastra merupakan hasil pembaca dalam menemukan nilai yang terdapat dalam karya sastra melalui pemahaman yang diwujudkan dalam bentuk tertulis.

Berdasarkan hasil wawancara dan observasi pada kegiatan pembelajaran menulis teks drama masih ditemukan kendala. Seperti guru menggunakan metode ceramah dalam penyampaian materi. Guru hanya menjelaskan struktur teks drama serta urutan dalam menulis teks drama. Sehingga pembelajaran di kelas masih kurang maksimal. Kendala dalam menulis teks drama juga dialami oleh siswa. Siswa kurang tertarik dan kesulitan dalam menulis teks drama. Hal tersebut senada dengan penelitian yang dilakukan oleh Krisbiono, Supriyanto, \& Rustono (2015) yang menunjukkan bahwa dalam menulis teks drama siswa masih kurang senang dan merasa kesulitan. Timbul rasa malas pada siswa dalam menentukan tema untuk dijadikan teks drama yang lengkap (Nuke, 2019).

Untuk memberikan solusi atas permasalahan-permasalahan dalam menulis teks drama yang dihadapi oleh siswa, selanjutnya dicarikan solusi dengan menerapkan metode pembelajaran quantum. Metode quantum berawal dari usaha Dr. Georgi Lozanov, pendidik yang bekebangsaan Bulgaria. Metode ini dimulai di Super Camp yang bereksperimen dengan suggestology atau suggestopedia (DePorter \& Hernacki, 2010). Sugestology memiliki istilah lain yakni accelerated learning atau percepatan belajar. Menurutnya, hasil belajar siswa dapat dipengaruhi oleh sugesti positif maupun negatif. Accelerated learning memungkinkan siswa untuk belajar dengan kecepatan mengagumkan dengan usaha yang normal serta kesukacitaan. Menurut Lestari (2018) quantum learning adalah metode pembelajaran yang menggembirakan dan melibatkan seluruh dinamika yang membantu dalam kesuksesan belajar dan seluruh keterikatan, perbandingan, korelasi, serta faktor-faktor yang dapat mengoptimalkan momen untuk belajar. Melalui metode quantum, setiap orang dapat memperlihatkan sikap belajar yang optimal, sehingga siswa dapat memaksimalkan sistem belajar sebagai pijakan untuk menggapai keberhasilan (Qalsum, 2018).

Metode pembelajaran quantum memiliki banyak manfaat antara lain perilaku yang positif, insentif, keterampilan untuk belajar selama hidup, percaya diri dan berhasil (DePorter \& Hernacki, 2010). Selanjutnya DePorter dalam Ahsin, (2016) mengembangkan metode pembelajaran quantum menggunakan sebutan "TANDUR", 


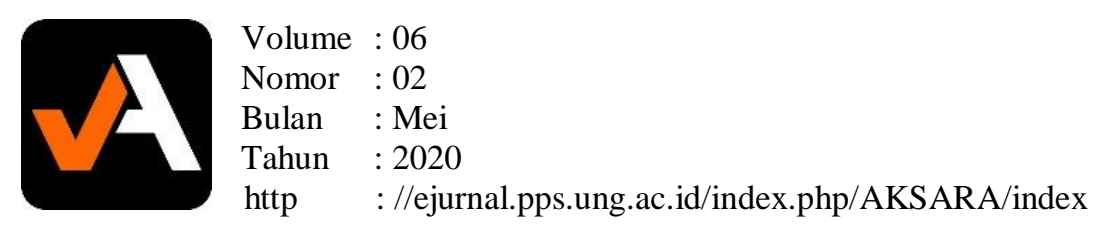

antara lain; 1) tumbuhkan, yaitu berikan apersepsi agar motivasi belajar siswa bertambah serta mengetahui AMBAK (Apa Manfaatnya Bagiku), 2) alami, setiap siswa diberikan pengalaman yang aktual kemudian mencoba, 3) namai, berikan istilah kunci, ide, acuan, formula, dan rencana, 4) demonstrasikan, sediakan peluang untuk siswa memperlihatkan kapasitasnya, 5) ulangi, berikan siswa kesempatan mengulang hal yang sudah dipelajari, 6) Rayakan, memberikan penghargaan kepada siswa atas partisipasinya dalam kegiatan keterampilan sebagai bentuk respon yang sepadan.

Hasil penelitian Hasanudin \& Asror (2017) menunjukkan bahwa quantum learning menghasilkan keterampilan membaca lebih baik. Mengakomodasi siswa untuk meningkatkan keterampilan membaca nyaring baik suku kata, kata maupun kalimat dengan ucapan serta tekanan secara tepat. Pembelajaran quantum memberikan efek kepada siswa mengenai keterampilan berpikir tingkat tinggi (Saputro \& Latifah, 2018). Penelitian yang dilakukan oleh Kisnanto, Sholehuddin, \& Setiyono (2019) menunjukkan hasil pembelajaran quantum learning dengan pendekatan scientific memberikan prestasi belajar yang lebih baik dibandingkan siswa yang diajar memakai pembelajaran konvensional. Dari hasil penelitian tersebut dapat disintesiskan bahwa quantum learning adalah metode pembelajaran yang inovatif untuk membangkitkan semangat dan motivasi siswa dalam belajar. Sehingga penelitian ini penting dilakukan karena metode quantum jika diterapkan dalam pembelajaran menulis teks drama akan mempermudah siswa dalam menerima materi pembelajaran dan dapat menulis teks drama sesuai dengan indikator yang telah ditentukan.

Berdasarkan permasalahan yang ditemukan dan berdasarkan penelitian yang relevan mengenai keterampilan menulis teks drama dengan pembelajaran quantum maka perlu dilakukan penelitian mengenai "Analisis Keterampilan Menulis Teks Drama dengan Pembelajaran Quantum".

\section{METODE PENELITIAN}

Penelitian ini adalah penelitian deskriptif kualitatif menggunakan jenis penelitian studi kasus. Menurut Mulyadi (2011) penelitian kualitatif menggantikan paham fenomenologis atau naturalistik. Penelitian kualitatif tidak memakai statistik (angka), namun dengan akumulasi data, analisis, selanjutnya diinterpretasikan atau ditafsirkan (Anggito \& Setiawan, 2018). Data yang diperoleh pada penelitian ini adalah bagaimana bentuk teks drama (prolog, orientasi, komplikasi, resolusi, epilog) yang ditulis oleh siswa kelas VIII MTs. Darussalam Deru, Sumberrejo, Bojonegoro, Indonesia ketika diajar dengan menggunakan pembelajaran quantum. Subjek pada penelitian ini berjumlah 28 Siswa. Dari 28 siswa diambil lagi 5 siswa untuk diwawancarai dengan alasan kemampuan menulis teks dramanya bagus. Sumber data dalam penelitian adalah subjek dari mana sebuah data didapatkan (Arikunto, 2006). Dalam penelitian ini yang dimaksud sumber data adalah siswa kelas VIII MTs. Darussalam Deru Kecamatan Sumberrejo. Data yang didapat dari siswa berwujud hasil tes mengenai materi keterampilan menulis teks drama dan wawancara dengan siswa tersebut.

Tujuan penting dari pengumpulan data pada penelitian ini adalah untuk memperoleh data. Dalam penelitian ini untuk memperoleh data penelitian melakukan prosedur pengumpulan data sebagai berikut: 


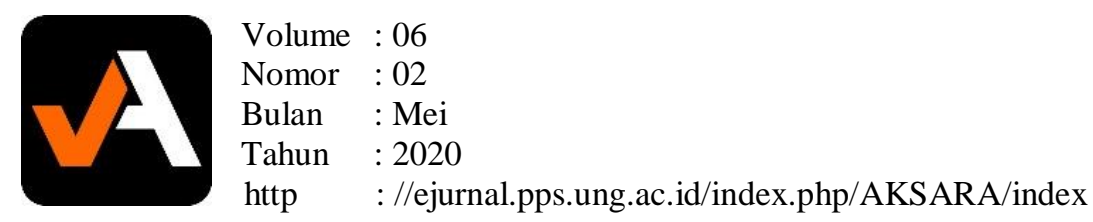

\section{Observasi}

Metode observasi digunakan untuk memeriksa dan mempelajari secara langsung kondisi di lapangan supaya peneliti mendapatkan keterangaan yang lebih mendalam mengenai persoalan yang diteliti. Penelitian ini memakai observasi terbuka atau langsung. 2. Metode Tes

Tes adalah sekumpulan pertanyaan atau latihan dan alat lain yang dipakai untuk menilai kecakapan, intelegensi, kompetensi yang dimiliki oleh perseorangan maupun kelompok (Arikunto dalam Wahyuni \& Maureen, 2010). Tes menulis digunakan untuk mengetahui keterampilan menulis teks drama siswa kelas VIII MTs. Darussalam Deru Kecamatan Sumberrejo. Tes menulis dilakukan oleh siswa secara individu setelah diajar dengan menggunakan pembelajaran quantum. Hasil tes kemudian dianalisis untuk mengetahui keterampilan menulis teks drama siswa sesuai dengan indikator. Adapun langkah-langkah yang dilakukan oleh peneliti dalam penghimpunan data dengan tes adalah a) siswa menyiapkan kertas untuk menulis teks drama, b) mengawasi siswa dalam menulis teks drama, c) hasil tes menulis dikumpulkan, d) hasil tes menulis dianalisis.

3. Metode Wawancara

Pada penelitian ini wawancara dilakukan oleh peneliti secara tak berstruktur. Wawancara tak berstruktur dipilih dalam penelitian ini, sebab wawancara tak berstruktur pada umumnya sinkron dengan pribadi siswa, lebih independen sehingga subyek tidak merasa bosan dalam berbagi suatu persoalan. Langkah-langkah yang peneliti lakukan dalam mengumpulkan data dengan wawancara adalah sebagai berikut a) menyusun kaidah wawancara tak terstruktur, b) wawancara dilakukan secara terang-terangan antara siswa dan peneliti sebagai pewawancara, c) wawancara dilakukan pada 5 siswa yang sesuai dengan indikator. Butir pertanyaan di kembangkan dari hasil menulis teks drama yang siswa lakukan, d) hasil wawancara dianalisis sehingga didapatkan hal yang berhubungan dengan daya cipta atau kreativitas siswa dalam menulis teks drama.

4. Dokumentasi

Menurut Fitrah \& Luthfiyah (2017) dokumentasi adalah sumber informasi (data) yang dipakai untuk menyempurnakan suatu penelitian, baik berbentuk sumber yang tertulis, gambar, film, serta karya-karya bersejarah, yang seluruhnya memberi informasi pada mekanisme atau proses penelitian.

Pada penelitian ini teknik analisis data yang digunakan merujuk pada teori Miles and Hubermen dalam Sayidah (2018:) meliputi:

1. Reduksi Data (Data Reduction)

Reduksi data adalah mekanisme penyempurnaan data yang telah didapatkan oleh peneliti, kemudian data-data tersebut akan dikurangi atau ditambahi sesuai dengan kebutuhan dalam penelitian. Tahap reduksi data pada penelitian ini yaitu a) mengoreksi hasil pekerjaan siswa menulis teks drama yang sesuai indikator, b) melaksanakan wawancara dengan dengan subjek yang sesuai indikator, kemudian hasil wawancara disusun dengan baik dan teliti.

2. Penyajian Data (Data Display)

Setelah melalui proses reduksi data, kemudian data diolah dan selanjutnya data disajikan dalam penjabaran yang singkat dan rinci. Tahap penyajian data pada penelitian ini yaitu a) menampilkan hasil pekerjaan siswa yang sudah diseleksi sebagai subjek peneliti, b) menyajikan hasil wawancara yang sudah direkam pada hp (hand phone). 


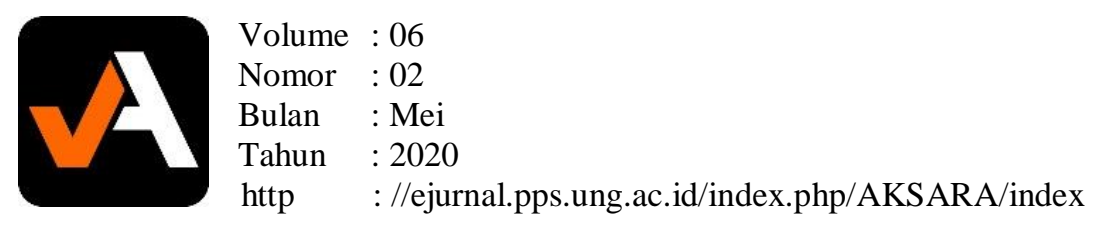

\section{Penarikan Kesimpulan dan Verifikasi}

Penarikan kesimpulan didapatkan setelah dilakukan interpretasi (penafsiran) data terhadap data yang sudah ditampilkan sebelumnya. Penafsiran dilakukan secara objektif, sehingga hasil penelitian ditemukan dan penarikan kesimpulan dapat dilakukan. Dengan membandingkan hasil pekerjaan siswa dan wawancara, bisa ditarik kesimpulan keterampilan menulis teks drama siswa.

Validasi data pada penelitian ini menggunakan teknik triangulasi. Triangulasi adalah melihat objek fakta (realitas) dari beragam sudut pandang, dari beragam aspek sehingga lebih teruji atau kredibel dan akurat (Suparno, 2008). Triangulasi yang digunakan pada penelitian ini adalah triangulasi sumber data dan triangulasi metode. Pada triangulasi sumber data, peneliti membandingkan data hasil tes dan wawancara. Pada triangulasi metode, peneliti menggunakan lebih dari satu metode pengumpulan data untuk mendapatkan data yang sama. Peneliti melakukan tes menulis teks drama kemudian diklarifikasi dengan wawancara.

\section{HASIL DAN PEMBAHASAN} Hasil

Hasil teks drama yang ditulis oleh siswa adalah sebagai berikut.

Berdasarkan pada teori Kosasih mengenai indikator menulis teks drama, berikut bentuk teks drama yang ditulis oleh siswa pada mata pelajaran bahasa Indonesia. Struktur pertama adalah prolog. Bentuk prolog pada teks drama yang ditulis siswa adalah sebagai berikut.

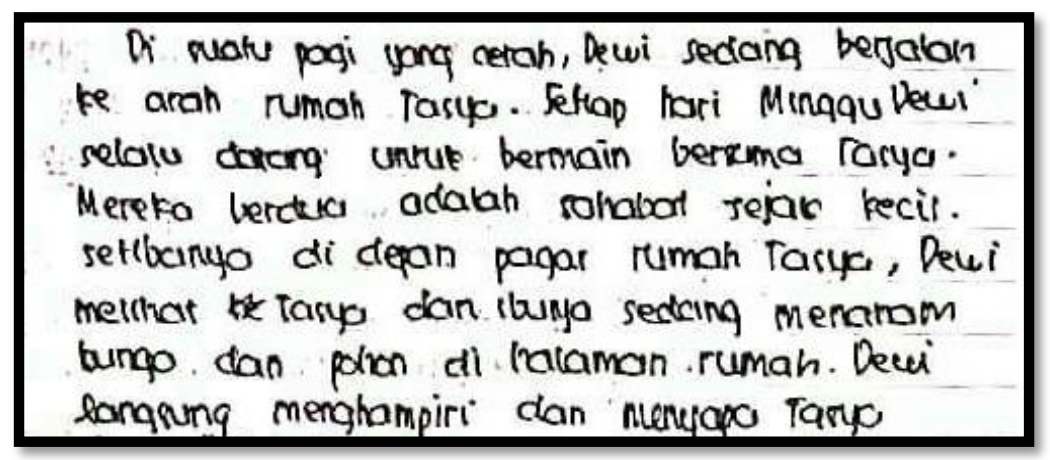

Gambar 1. Prolog pada teks drama

Pada lembar tes menulis teks drama. Siswa membuat prolog dengan mendeskripsikan gambaran latar dan gambaran para pemain. Isi prolog berisi tentang peristiwa pendahuluan dalam teks drama. Berdasarkan teks yang ditulis oleh siswa, kita bisa mengetahui siswa mampu membuat prolog sesuai dengan kaidah teks drama. Saat peneliti bertanya, mengapa dia menulis seperti itu, dia menjelaskan bahwa ide tersebut datang karena pernah melihat tetangganya menanam pohon. Hal ini bisa dilihat pada kutipan wawancara berikut.

$\mathrm{P}$ : "Apakah kamu sudah memahami struktur menulis teks drama?"

S1 : "Sudah, Bu!" 


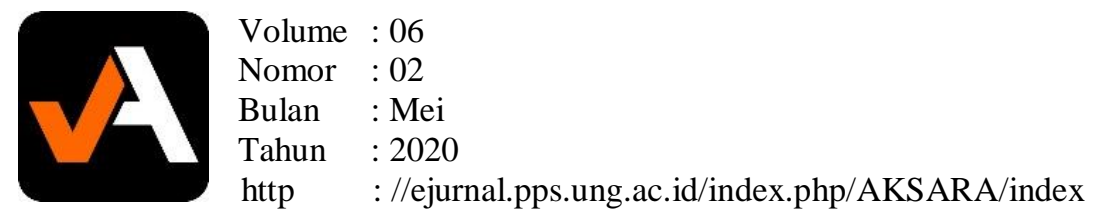

P : "Kamu sudah paham konsep prolog pada teks drama?"

S1 : "Sudah, Bu"

$\mathrm{P} \quad$ : "Mengapa saudara membuat prolog teks drama dengan latar di pagi hari dan menanam pohon?"

S1 : "Karena saya pernah melihat tetangga saya menanam pohon di depan rumahnya saat pagi hari",

Struktur kedua adalah orientasi. Bentuk orientasi yang siswa tulis pada teks drama adalah sebagai berikut.

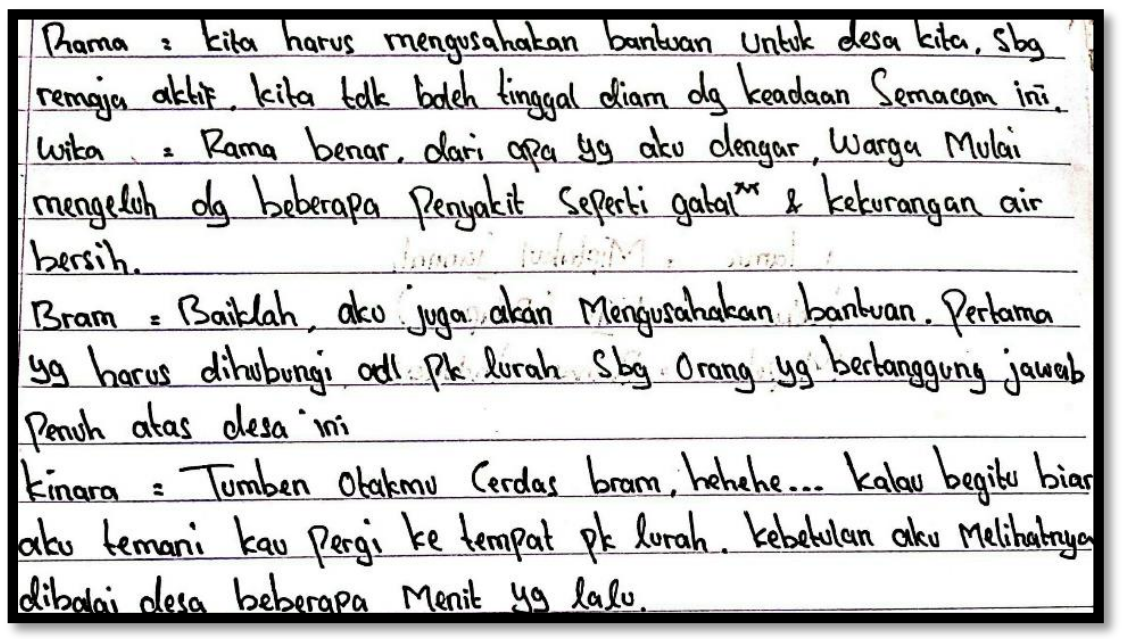

Gambar 2. Orientasi pada teks drama

Pada lembar tes menulis teks drama ini. Siswa membuat orientasi dengan menyertakan tokoh Rama, Wika, Bram, dan Kinara. Rama mengajak teman-temannya untuk mengusahakan bantuan untuk desanya yang terkena banjir. Pada poin orientasi ini, siswa telah mampu membuat dengan baik dan benar struktur teks drama. Peneliti mewawancarai siswa mengapa menulis seperti itu, dia mengatakan bahwa kondisi seperti ini sering dia lihat pada berita di televisi. Hal ini dapat dilihat pada kutipan wawancara berikut.

$\mathrm{P}$ : "Saudara sudah memahami struktur teks drama?"

S2 : "Sudah"

P : "Mengapa Saudara membuat orientasi dengan melibatkan tokoh Rama, Wika, Bram, dan Kinara?"

S2 : "Karena kondisi yang sering hujan sekarang ini, saya sering melihat berita di televisi tentang banjir, sehingga saya mampu membuat teks drama pada bagian orientasi”

Struktur ketiga adalah komplikasi. Bentuk komplikasi pada teks drama yang ditulis oleh siswa dapat dilihat pada gambar berikut. 


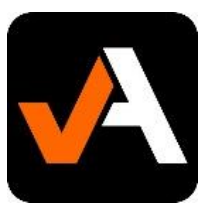

Volume : 06

Nomor : 02

Bulan : Mei

Tahun : 2020

http : //ejurnal.pps.ung.ac.id/index.php/AKSARA/index

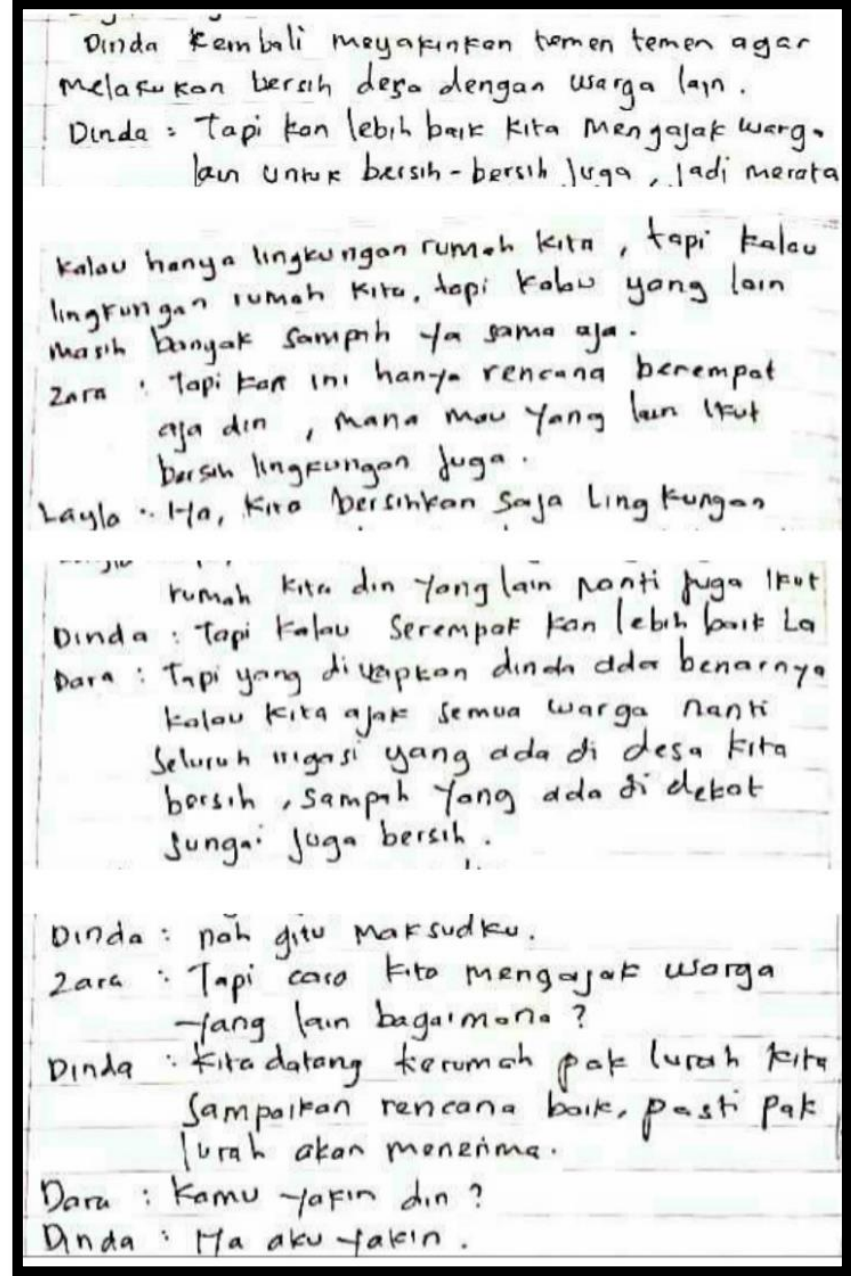

Gambar 3. Komplikasi pada teks drama

Pada lembar tes menulis teks drama ini, siswa menulis teks drama pada bagian komplikasi dengan melibatkan tokoh Dinda dan ketiga sahabatnya yaitu Zara, Layla dan Dara. Komplikasi yang ditulis oleh siswa berisi konflik dalam mencapai tujuan yaitu bersih desa dengan mengajak warga yang lain secara serempak. Halangan tersebut terlihat saat Dinda mengusulkan kegiatan bersih desa bersama semua warga, namun ketiga sahabatnya merasa ragu warga yang lain bersedia melakukannya. Ketika peneliti menanyakan mengapa siswa menulis itu, dia menjawab bahwa berdasarkan latihan menulis komplikasi sebelumnya, akhirnya saya mampu menulis komplikasi dengan lebih baik. Hal ini dapat dilihat pada kutipan wawancara berikut.

$\mathrm{P}$ : "Saudara sudah memahami bagian komplikasi pada teks drama?"

S3 : "Sudah, Bu"

$\mathrm{P}$ : "Mengapa saudara membuat komplikasi seperti itu?"

S3 : "Karena saya sudah berlatih saat Bu Guru meminta saya menulis bagian komplikasi, akhirnya saya mampu menulis komplikasi dengan lebih baik, Bu" 
Struktur keempat adalah resolusi. Resolusi pada teks drama yang ditulis oleh siswa dapat dilihat pada gambar berikut.

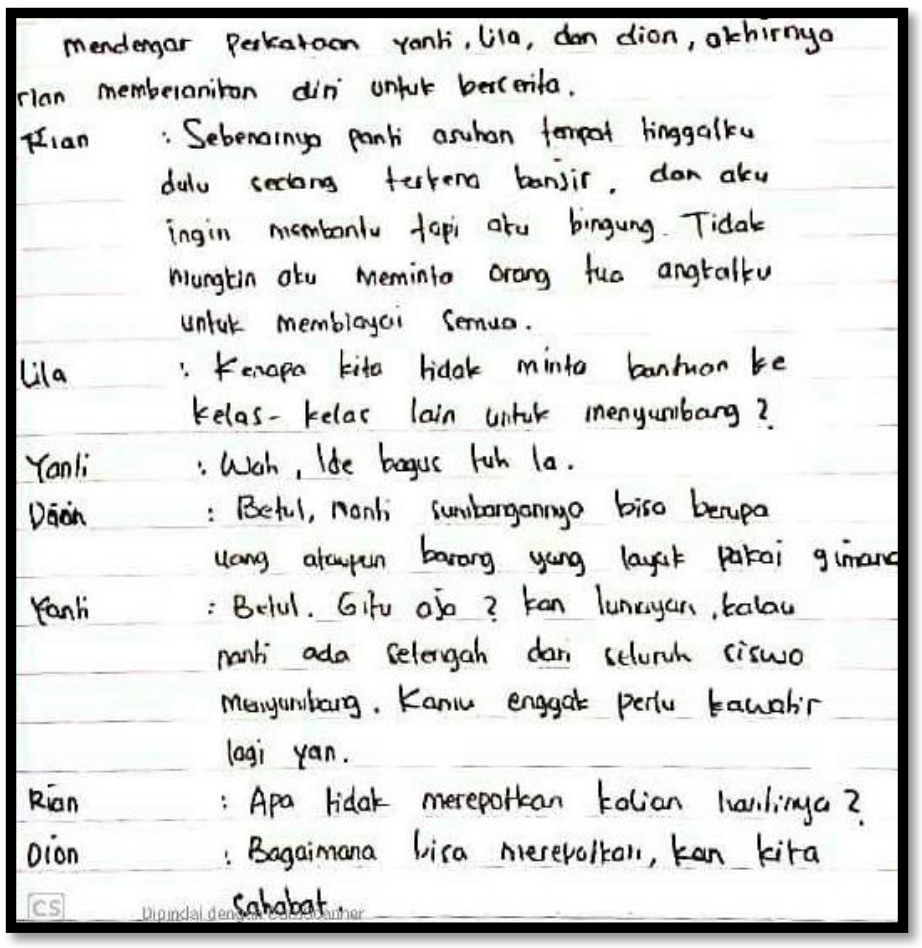

Gambar 4. Resolusi pada teks drama

Pada lembar tes menulis teks drama ini. Bentuk resolusi pada teks drama yang siswa tulis menggambarkan penyelesaian konflik yang dialami para tokoh. Tokoh Rian akhirnya menceritakan masalahnya kepada tokoh Yanti, Lila dan Dion. Ketika peneliti melangsungkan wawancara dengan siswa, mengapa siswa menulis resolusi seperti ini, dia menjawab pernah melihat sinetron di televisi, sehingga saya terinspirasi untuk menulis resolusi seperti pada teks drama tersebut. Hal ini dapat dilihat pada kutipan wawancara berikut.

$\mathrm{P} \quad$ : "Mengapa kamu menulis bagian resolusi seperti ini?"

S4 : "Karena saya pernah melihat sinetron di televisi, jadi saya membuat teks drama pada bagian resolusi seperti pada teks tersebut. Tokoh Rian akhirnya menceritakan masalah yang dialami kepada ketiga sahabatnya"

Struktur kelima adalah epilog. Epilog pada teks drama yang ditulis oleh siswa dapat dilihat pada gambar berikut. 


Dany dan Nurma Jenang nelifhat Adi
sudah tidak sedih lagi. Setelah bel pulang
sekolah, Adi pulang bersama Dany unfuk
meminjam hip dan menghubungi leluarganya
yang terkena badir di Jakarta.

Gambar 5. Epilog pada teks drama

Pada lembar tes menulis teks drama ini, siswa menulis bagian epilog pada teks drama dengan melibatkan tokoh Dany, Nurma dan Adi. Siswa membuat epilog berdasarkan contoh yang telah diberikan oleh Guru. Siswa membuat epilog melibatkan tokoh Dany, Nurma dan Adi dalam mengakhiri bagian teks drama. Saat peneliti melakukan wawancara dengan siswa, mengapa dia menulis seperti itu, dia mengatakan bahwa saat Bu Guru meminta saya untuk 2 kali menulis epilog, saya masih kesulitan, namun yang ketiga saya sudah bisa. Hal ini dapat dilihat pada kutipan berikut.

P : "kamu pernah mengalami hal yang kamu tulis pada bagian epilog ini, Nak?"

S5 : "Tidak, Bu!"

$\mathrm{P}$ : "Mengapa kamu menulis epilog pada teks drama seperti itu?"

S5 : "Ketika Bu Guru meminta saya untuk menulis epilog 2 kali, saya masih kesulitan. Namun, yang ketiga saya sudah bisa. Sehingga saya menulis epilog seperti ini”

\section{Pembahasan}

Merujuk pada struktur menulis teks drama yang diungkapkan oleh Kosasih. Struktur teks drama yang dibuat oleh siswa kelas VIII MTs. Darussalam Deru, Sumberrejo, Bojonegoro, Indonesia sudah mengacu pada struktur teks drama sesuai teori Kosasih dengan benar.

Pada bagian prolog teks drama. Siswa menulis bagian prolog berdasarkan ide yang ada dipikirannya. Ide prolog ini berasal dari pengalaman sebelumnya yaitu ketika siswa melihat tentangganya menanam pohon di pagi hari. Prolog merupakan peristiwa pendahuluan pada sebuah drama. Prolog menggambarkan gambaran para pemain, latar, dan sebagainya. Prolog menurut O'Sullivan, Schoenenberger, \& Kingston (2016) dapat diartikan sebagai adegan pembuka dan ini merupakan pembangun teks drama. Hasil penelitian Herdianingsih \& Akbar (2018) menunjukkan bahwa penulisan skenario tokoh lokal Mbojo berisi pesan prolog (percakapan) cerita.

Pada bagian orientasi teks drama. Siswa mampu menulis dengan baik. Bagian orientasi yang ditulis oleh siswa menggambarkan situasi yang sedang terjadi. Orientasi siswa melibatkan tokoh Rama yang mengajak sahabatnya untuk mengusahakan bantuan bagi desanya yang tekena musibah banjir.

Pada bagian komplikasi teks drama. Siswa menulis bagian komplikasi dengan menyertakan tokoh Dinda, dan ketiga sahabatnya. Bentuk komplikasi dibuktikan dengan adanya konflik ketika Dinda mengusulkan kegiatan bersih desa bersama seluruh warga, 


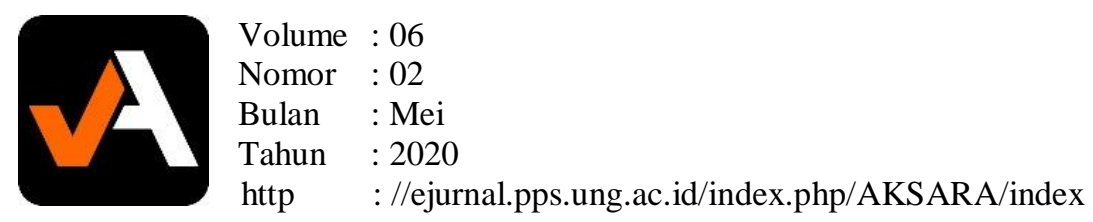

namun ketiga sahabatnya merasa ragu warga yang lain bersedia melakukannya, sehingga terjadi adu argumen di antara mereka

Pada bagian resolusi teks drama. Siswa menulis bagian resolusi berdasarkan cerita yang pernah ia lihat di televisi. Teks yang ditulis melibatkan tokoh Rian, Yanti, Lila dan Dion. Resolusi adalah bagian klimaks, berupa babak akhir cerita yang menggambarkan penyelesaian konflik yang dialami para tokoh. Resolusi yang ditulis siswa yaitu ketika tokoh Rian akhirnya menceritakan masalahnya kepada Yanti, Lila, dan Dion.

Pada bagian epilog teks drama. Siswa dapat menulis dengan benar. Bagian epilog yang ditulis siswa menggambarkan inti sari cerita yang melibatkan tokoh Dany, Nurma dan Adi. Bentuk epilog dibuktikan dengan tokoh Dany dan Nurma merasa senang melihat Adi sudah tidak sedih lagi karena bisa menghubungi keluarganya yang terkena banjir di Jakarta.

Kemampuan siswa kelas VIII MTs. Darussalam Deru, Sumberrejo, Bojonegoro, Indonesia dalam menulis teks drama sesuai dengan struktur teks drama menunjukkan bahwa pembelajaran quantum sangat cocok diterapkan pada kompetensi dasar 4.16. penerapan pembelajaran quantum memberikan pembaruan dalam proses belajar pembelajaran serta siswa terdorong untuk mempelajari materi pembelajaran.

\section{SIMPULAN}

Bentuk teks drama yang ditulis oleh siswa kelas VIII MTs. Darussalam Deru, Sumberrejo, Bojonegoro, Indonesia pada pembelajaran dengan menerapkan pembelajaran quantum telah mengacu pada struktur teks drama sesuai dengan teori Kosasih dengan baik. Pada bagian prolog, siswa menulis prolog berdasarkan ide yang ada dipikirannya. Pada bagian orientasi, siswa menulis orientasi yang menggambarkan kejadian yang sedang terjadi. Pada bagian komplikasi, siswa menulis komplikasi dengan adanya konflik antara Dinda dan ketiga sahabatnya. Pada bagian resolusi, siswa menulis resolusi berdasarkan cerita yang pernah ia lihat di televisi. Pada bagian epilog, siswa menulis epilog yang menggambarkan inti sari cerita dengan melibatkan tokoh Dany, Nurma, dan Adi.

\section{DAFTAR PUSTAKA}

Ahsin, M. N. (2016). Peningkatan keterampilan menulis karangan narasi dengan menggunakan media audiovisual dan metode Quantum Learning. Jurnal Refleksi Edukatika, 6(2), 158-171. https://jurnal.umk.ac.id/index .php/RE/ article/view/607

Anggito, A. \& Setiawan, J. (2018). Metodologi penelitian kualitatif. Sukabumi: CV. Jejak.

Arikunto, S. (2006). Prosedur penelitian suatu pendekatan praktik. Jakarta: PT Asdi Mahasatya.

DePorter, B. dan Hernakci M. (2010). Quantum learning, membiasakan belajar nyaman dan menyenangkan. Terjemahan Alwiyah Abdurrahman. Bandung: PT Mizan Pustaka.

Fitrah, M., \& Luthfiyah (2017). Metodologi penelitian; penelitian kualitatif, tindakan kelas \& studi kasus. Sukabumi: CV Jejak.

Hasanudin, C. dan Asror, A. G. (2017). Efektivitas model pembelajaran quantum learning dengan media aplikasi bamboomedia bmgames apps terhadap 


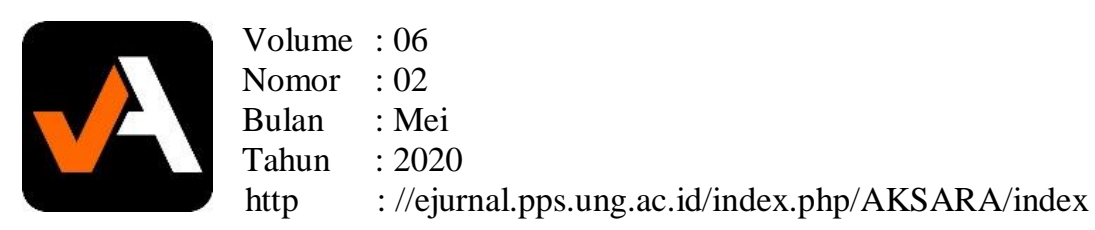

keterampilan membaca permulaan pada siswa kelas I MI se-kecamatan Kedungadem. Pedagogia, 6(2), 150-159. Retrieved from http://ojs.umsida.ac .id/index.php/pedagogia/article/view/907/774

Herdianingsih, S. \& Akbar, M. R. (2018). Pelestarian tokoh lokal masyarkat Bima melalui kemampuan mahasiswa dalam menulis teks drama. Jurnal Pendidikan Bahasa, 8(1), 46-52. Retrieved from http://ejournal.tsb.ac.id/index.php/jpb/article/view/99/88.

Hidayah, R. N., Darmuki, A. \& Hasanudin, C. (2019). Peningkatan keterampilan menulis puisi dengan menggunakan metode quantum learning dan media video pada siswa kelas X IPA I SMA Negeri 2 Blora tahun ajaran 2018/2019. Jurnal linguistik, sastra, dan pendidikan, 4(1), 309-320. Retrieved from http://ejournal .unwmataram.ac.id/trendi/article/view/152

Iswara, A. D. (2019). Penerapan metode kooperatif tipe jigsaw pada pembelajaran menulis teks drama siswa kelas VIII SMP Negeri 1 Driyorejo. Jurnal BAPALA, 1(1), 1-8. Retrieved from https://jurnalmahasiswa.unesa.ac.id/index.php/bapala /ar ticle/view/29796

Kisnanto, I., Sholehuddin, M., \& Setiyono J. (2019). Eksperimentasi model pembelajaran quantum learning berbasis pendekatan scientific terhadap hasil belajar siswa pada pokok bahasan puisi. Jurnal genre, 1(1), 36-41. Retrieved from http://journal2.uad.ac.id/index.php/genre/article/view/1058

Krisbiono, Supriyanto, \& Rustono. (2015). Keefektifan model sinektik dan model simulasi dalam pembelajaran menulis teks drama berdasarkan gaya belajar pada peserta didik kelas XI SMA. Jurnal pendidikan bahasa dan sastra Indonesia, 4(2), 125-130. Retrieved from https://journal.unnes.ac.id/sju/index.php/seloka /article/vi ew/9870/6310

Lestari, I. (2018). Penerapan model pembelajaran mind mapping dalam metode quantum learning untuk meningkatkan hasil belajar. Jurnal pendidikan dan pembelajaran, 3(3), 231-239. Retrieved from http://ojs.iptpisurakarta.org/in dex.php/Edudikara/article/view/5/2

Mulyadi, M. (2011). Penelitian kuantitatif dan kualitatif serta pemikiran dasar menggabungkannya. Jurnal studi komunikasi dan media, 15(1), 127-138. Retrieved from http://jurnal.kominfo.go.id/index.php/jskm/article/download /52/49

Nuke, A. (2019). Peningkatan keterampilan menulis naskah drama dengan menggunakan media short film pada peserta kelas VIII DI SMP Negeri 3 Jombang tahun pelajaran 2018/2019. Jurnal pendididikan Bahasa dan sastra Indonesia, 7(2), 39-48. Retrieved from https://ejournal.stkipjb.ac.id/index.php/sastra/article/view/1291/ 1003

O'Sullivan, C., Schoenenberger, H., \& Kingston, P. 2016. The Impact of Live Performance in Primary Schools in Ireland: A Case Study of the Abbey Theatre's Priming the Canon Programme. National Drama Publications, 7(1)

Permanasari, D. (2019). Kemampuan menulis teks drama pada siswa kelas VIII SMP Negeri 25 Bandar Lampung. Jurnal kajian Bahasa dan sastra, 1(1), 57-62. Retreived from http://jurnal.stkippgribl.ac.id/index.php/ksatra/article/view/13 


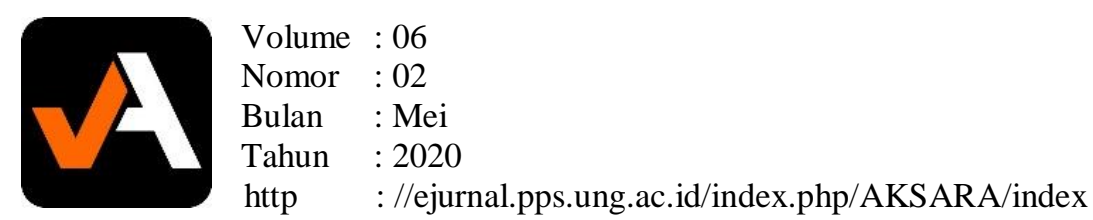

Pratiwi, N. W. E. S. (2018). Kemampuan siswa kelas VIII B SMP Negeri 1 Torue dalam menulis teks berita. Jurnal Bahasa dan sastra, 3(4), 1-11. Retreived from http://jurnal.untad.ac.id/jurnal/index.php/BDS/article/view/10528/8287

Qalsum, U. (2018). Penerapan metode quantum learning dalam upaya meningkatkan hasil belajar siswa kelas VIII.A SMP pesantren Datok Sulaiman Palopo khususnya pada pembelajaran bahasa Indonesia. Jurnal onoma: pendidikan, bahasa dan sastra, 4(2), 92-104. Retrieved from http://journal.uncp.ac.id/ index.php/onoma /article/view/1119

Rahimah, Priyadi, A. T., \& Syambasril (2018). Pelaksanaan pembelajaran teks drama berdasarkan kurikulum 2013 di SMPN 10 Pontianak. Jurnal pendidikan dan pembelajaran, 7(7), 1-10. Retrieved from http://jurnal.untan.ac.id/index.php /jpdp b/article/view/26639

Saputro, T. dan Latifah S. (2018). Efektivitas metode pembelajaran quantum learning terhadap kemampuan berpikir tingkat tinggi peserta didik kelas X MA nurul islam gunung sari Ulubelu Tanggamus. Indonesian journal of science and mathematics education, 1(2), 29-37. Retrieved from http://ejournal.radenintan .ac.id/index.php /IJSME/article/view/2770/2034

Satinem. (2019). Apresiasi prosa fiksi: teori, metode dan penerapannya. Ngaglik, Sleman, Indonesia: CV. Budi Utama.

Sayidah, N. (2018). Metodologi penelitian disertai dengan contoh penerapannya dalam penelitian. Sidoarjo: Zifatma Jawara.

Sobari, T. (2012). Penerapan teknik siklus belajar dalam pembelajaran menulis laporan ilmiah berbasis vokasional di SMK. STIKIP Siliwangi Jornals, 1(1), 17-41. Retrieved from http://www.ejournal.stkipsiliwangi.ac.id/index.php/semantik/ article/view/98

Suparno, P. (2008). Riset tindakan untuk pendidik. Jakarta: PT. Grasindo.

Tambunan, B. dan Naelofaria, S. (2019). Efektivitas model novick terhadap keterampilan menulis teks drama pada siswa kelas VIII SMP swasta angkasa lanud soewondo Medan tahun pembelajaran 2018/2019. Jurnal basastra, 8(2), 191-200. Retrieved from https://jurnal.unimed.ac.id/2012/index.php/basastra/ article/view/ 14470

Wahyuni, N., \& Maureen, I. Y. (2010). Pemanfaatan media puzzle metamorfosis dalam pembelajaran sains untuk meningkatkan hasil belajar siswa kelas II SDN Sawunggaling I/382 Surabaya. Jurnal mahasiswa teknologi pendidikan, 1(2), 1-13. Retrieved from https://jurnalmahasiswa.unesa.ac.id/index.php/jmtp/artic le/view/1595

Yusandra, T. F. (2017). Struktur percakapan dalam teks drama Anggun Nan Tongga karya Wisran Hadi. Jurnal kata, 1(2). 117-130. Retrieved from https://ejournal. kopertis10.or.id/index.php/kata/article/view/2112 